EFFICINT

\title{
Study of the Collection and Potency of Rural and Urban Land and Building Tax
}

\author{
Sofiatun Nisa', Yozi Aulia Rahman² \\ Jurusan Ekonomi Pembangunan, Fakultas Ekonomi, Universitas Negeri Semarang \\ Permalink/DOI: https://doi.org/10.15294/efficient.v2i1.28448
}

Received: July 2018 ; Accepted: October 2018 ; Published: January 2019

\begin{abstract}
The purpose of this research is to find out and analyze the development, classification, and strategy of increasing Rural and Urban Land and Building Tax revenue in Kendal Regency. The method used in this research is quantitative research method using five analyzes, namely growth analysis, effectiveness analysis, contribution analysis, classification analysis, and AHP analysis (Analytical Hierarchy Process). The results of this study indicates that the growth of Rural and Urban Land and Building Tax revenues in Kendal Regency in 2014-2017 tends to increase, except in 2015. The average growth of Rural and Urban Land and Building Tax in Kendal Regency 2014-2017 amounted to 5.23\%. The average of effectiveness rate of Rural and Urban Land and Building Tax in Kendal Regency is 95.63\% included in the effective criteria. The average contribution of Rural and Urban Land and Building Tax to to Local Government Revenue (PAD) of Kendal Regency is 5.79\% with criteria very low contribution. The classification of Rural and Urban Land and Building Tax revenues in Kendal Regency $2015-2017$ belongs to the category of potential revenue. Based on the results of AHP, it can be seen that the strategy of increasing Rural and Urban Land and Building Tax revenues in Kendal Regency consists of several priority programs, namely: first, taxpayers participation (0.285); second, human resources of tax management (o.28o); third, tax administration and services $(0,248)$ and fourth, policy of tax management $(0,188)$.
\end{abstract}

Keywords: Development, Classification, Rural and Urban Land and Building Tax (PBB-P2), Analytical Hierarchy Process

\begin{abstract}
Abstrak
Tujuan dari penelitian ini adalah untuk mengetahui dan menganalisis pengembangan, klasifikasi, dan strategi peningkatan pendapatan Pajak Bumi dan Bangunan di Kabupaten Kendal. Metode yang digunakan dalam penelitian ini adalah metode penelitian kuantitatif dengan menggunakan lima analisis, yaitu analisis pertumbuhan, analisis efektivitas, analisis kontribusi, analisis klasifikasi, dan analisis AHP (Analytical Hierarchy Process). Hasil penelitian ini menunjukkan bahwa pertumbuhan penerimaan Pajak Bumi dan Bangunan di Kabupaten dan Kota di Kabupaten Kendal pada tahun 2014-2017 cenderung meningkat, kecuali pada tahun 2015. Rata-rata pertumbuhan Pajak Bumi dan Bangunan di Kabupaten Kendal 2014-2017 sebesar 5,23\%. Rata-rata tingkat efektivitas Pajak Bumi dan Bangunan Pedesaan dan Perkotaan di Kabupaten Kendal adalah 95,63\% termasuk dalam kriteria efektif. Kontribusi rata-rata Pajak Bumi dan Bangunan Desa dan Perkotaan terhadap Pendapatan Pemerintah Daerah (PAD) Kabupaten Kendal adalah 5,79\% dengan kriteria kontribusi sangat rendah. Klasifikasi pendapatan Pajak Bumi dan Bangunan Pedesaan dan Perkotaan di Kabupaten Kendal 2015-2017 termasuk dalam kategori pendapatan potensial. Berdasarkan hasil AHP, dapat dilihat bahwa strategi peningkatan penerimaan Pajak Bumi dan Bangunan Desa dan Perkotaan di Kabupaten Kendal terdiri dari beberapa program prioritas, yaitu: pertama, partisipasi wajib pajak $(0,285)$; kedua, sumber daya manusia manajemen pajak (o,28o); ketiga, administrasi dan layanan pajak $(0,248)$ dan keempat, kebijakan manajemen pajak $(0,188)$.
\end{abstract}

Kata Kunci: Pengembangan, Klasifikasi, Pajak Bumi dan Bangunan Pedesaan dan Perkotaan (PBB-P2), Proses Hirarki Analitik

How to Cite: Nisa, S., \& Rahman, Y. (2019). Study of the Collection and Potency of Rural and Urban Land and Building Tax. EFFICIENT Indonesian Journal of Development Economics, 2(1), 354-361. https://doi.org/10.15294/efficient.v2i1.28448

(C) 2019 Semarang State University. All rights reserved

Alamat Korespondensi :

Alamat: Gedung L2 Lantai 2 FE Unnes

ISSN2655-6197

Kampus Sekaran, Gunungpati, Semarang, 50229

E-mail : efficientjournal@gmail.com 


\section{INTRODUCTION}

The implementation of regional autonomy since 2001 has provided opportunities for regions to develop regional economies in accordance with the potential of regional resources to improve the economy of the community and regional revenues (Ristanti, 2017). According to Law Number 23 Year 2014 concerning Regional Government, regional autonomy is the right, authority, and obligation of the autonomous region to regulate and manage their own government affairs and local community interests in the system of the Unitary State of the Republic of Indonesia.

According to Febiandani and Suseno (2016), problems that often occur in the implementation of regional autonomy and decentralization are fiscal dependencies that occur between regions and central government to finance the needs of regional development activities. Regional development especially physical quite rapid has made the level of fiscal dependence between regions to the center even greater, this can be seen from the relatively low to Local Government Revenue (PAD) and the dominant transfer from the center (Kuncoro, 2010). The efforts to reduce transfer dominance from the central government and to increase development and maximize the implementation of regional autonomy, the regional government must further increase PAD (Lianawati, 2015). Regional tax is one of the very important PAD sources for the region, because the results of tax collection will later be used for the government administration and regional development in the implementation of regional autonomy. One of the government policies regarding taxes for reforming Law
Number 34 Year 2000 became Law Number 28 Year 2009 concerning Regional Taxes and Regional Retribution. This Law Reform is aimed at empowering regional capabilities in financing development through taxes (local taxing power). Local taxing power is done in a way, one of which is to increase the type of local tax (Lianawati, 2015). New types of taxes that can be collected by regions (regencys / cities) include: Groundwater Taxes, Swallow Nest Taxes, Rural and Urban Land and Building Taxes (PBB-P2), and BPHTB.

Initially, PBB-P2 was a type of tax managed by the central government, but after the enactment of Law Number 28 Year 2009 concerning Regional Taxes and Regional Retribution, there was a transfer of $\mathrm{PBB}-\mathrm{P}_{2}$ management from the central government to regional (regency / city) governments. As a result of the transfer of $\mathrm{PBB}-\mathrm{P}_{2}$ to the regions, the process of data collection, assessment, administration, collection / billing and PBB-P2 services will be held by the local government (Directorate General of Tax, Ministry of Finance, 2012). The transition period of the transfer of PBB-P2 into local tax started from January 1, 2010 to December 31, 2013. Kendal Regency is one of the regions that began transferring PBB-P2 since January 1, 2014. The Regional Government of Kendal Regency issued the Kendal Regency Regional Regulation Number 11 Year 2011 concerning Regional Taxes, as a condition in carrying out the transfer of $\mathrm{PBB}-\mathrm{P}_{2}$ collection. When viewed from the revenue realization of 11 types of local taxes in Kendal Regency in 20142017, PBB-P2 is the third largest local tax after street lighting tax and BPHTB. The following table 1 is the target and $\mathrm{PBB}-\mathrm{P}_{2}$ revenue realization in Kendal Regency in 2014-2017: 
Tabel 1. Target and PBB-P2 Revenue Realization of Kendal Regency Year 2014 - 2017 (in Rupiah)

\begin{tabular}{llll}
\hline Year & Target & Realization & Information \\
\hline 2014 & 16.000 .000 .000 & 15.569 .254 .696 & Not Achieved \\
2015 & 15.569 .254 .696 & 13.907 .137 .665 & Not Achieved \\
2016 & 18.000 .000 .000 & 15.241 .220 .234 & Not Achieved \\
2017 & 16.000 .000 .000 & 17.797 .002 .224 & Achieved \\
\hline
\end{tabular}

Source: BAKEUDA KABUPATEN KENDAL, 2017

In Table 1, it can be seen that PBB-P2 revenue realization in Kendal Regency in 2014 to 2017 tends to increase, except in 2015 the realization of $\mathrm{PBB}-\mathrm{P}_{2}$ revenues decreased by Rp1.662.117.031. Although the PBB-P2 realization in Kendal Regency in 2014-2017 tends to increase, not all $\mathrm{PBB}-\mathrm{P}_{2}$ revenue realization can meet the set targets. In 20142016 PBB-P2 revenue realization had not reached the target set by the Regional Government of Kendal Regency. This shows that the management of PBB-P2 in Kendal Regency has not been maximized, so efforts are needed to increase $\mathrm{PBB}-\mathrm{P}_{2}$ revenue so that regional revenues from the regional tax sector will be greater in order to finance the implementation of governance and regional development in Kendal Regency.

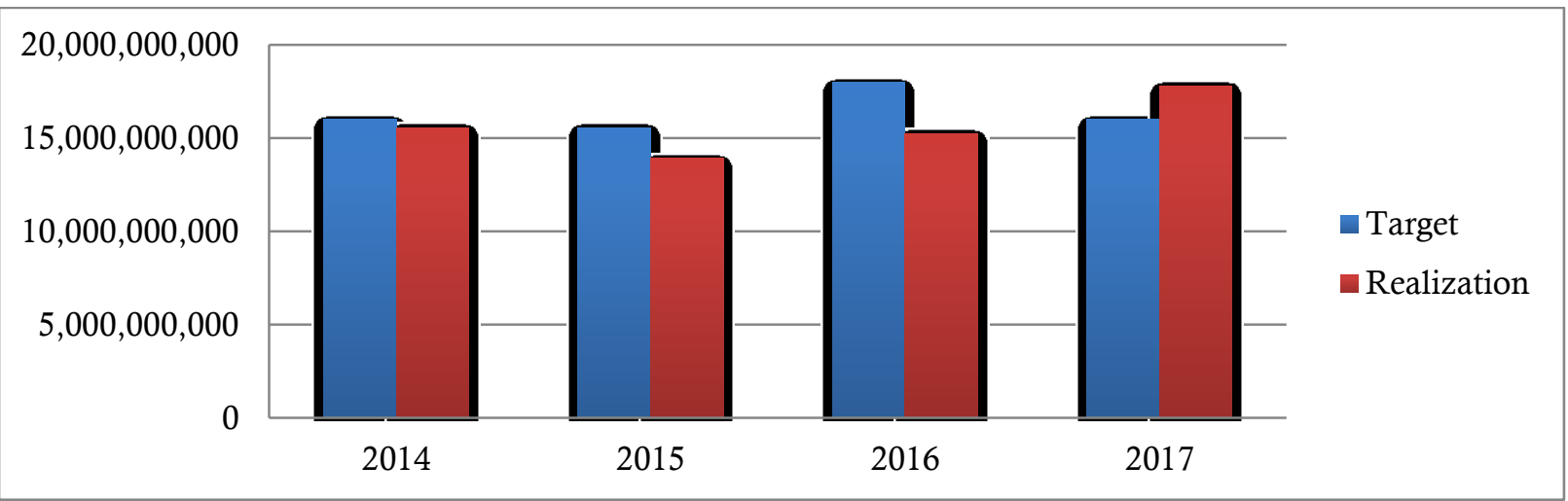

Figure 1. Chart of Target and PBB-P2 Revenue Realization of Kendal Regency 2014-2017 Source: (Kendal Regency BAKEUDA, 2017)

\section{RESEARCH METHODS}

The type of research used is quantitative research. The types of data used in this research are primary and secondary data. Primary data was obtained from observations, interviews with PBB-P2 management employees, Kendal Regency Regional Finance Agency and questionnaires given to the key persons to formulate policies in the Process
Hierarchy Analysis (AHP) in increasing PBB-P2 revenues in Kendal Regency. While the secondary data used in this study was obtained from the Kendal Regency Regional Finance Agency, the Law, and Kendal Regency Regional Regulation.

This research uses five methods of analysis namely growth analysis, effectiveness analysis, contribution analysis, classification 
analysis, and AHP analysis. The AHP method in question is used to find out which programs need to be prioritized in the strategy to increase PBB-P2 revenues in Kendal Regency. Therefore, this research requires several parties considered competent representing to determine alternatives in an effort to increase PBB-P2 revenues. This research uses 12 key persons consisting of 8 tax employees who participated in $\mathrm{PBB}-\mathrm{P}_{2}$ management and 4 sub-regency employees in Kendal Regency.

\section{RESULTS AND DISCUSSION}

The growth rate of PBB-P2 in Kendal Regency in 2014 to 2017 showed an increasing trend, except in 2015 PBB-P2 revenues experienced a negative growth of $10.68 \%$ or a decrease in revenue of Rp1.662.117.031 compared to the previous year. The highest PBB-P2 growth rate in Kendal Regency during 2014 to 2017 occurred in 2017 with a growth rate of $16.77 \%$. The average $\mathrm{PBB}-\mathrm{P} 2$ growth in Kendal Regency during the four years of the 2014 to 2017 period was $5.23 \%$.

The growth rate of $\mathrm{PBB}_{2} \mathrm{P}_{2}$ Kendal Regency in 2014 to 2017 tended to increase, this could be caused by the number of tax objects that increase each year. The decline in PBB-P2 revenue in 2015 was due to: first, the lack of public awareness about the importance of paying taxes for the implementation of development. Second, there was an intensive decline given to tax collection officers from the original $4-5 \%$ to $0.25 \%$. Third, the village or sub-village that succeeded in attracting PBB-P2 up to one hundred percent or the fastest repayment was given a prize, but in that year there were no prizes. Whereas the highest PBB-P2 growth rate occurred in 2017 because Kendal Regency Regional Finance Agency intensively conducted tax collection, especially for taxpayers having a large nominal tax value, such as: taxpayers who have large land, factories or companies, as well as taxpayers whose tax object is located near the protocol road.

$\mathrm{PBB}-\mathrm{P} 2$ revenue for the last four years after being transferred to local taxes shows that in 2014 to 2016 PBB-P2 revenues were classified as effective criteria with a value of $97.31 \%$ for 2014, the effectiveness of $89.32 \%$ for in 2015 and $84 \%$ for 2016. While $\mathrm{PBB}-\mathrm{P}_{2}$ revenue in 2017 was included in the very effective criteria with an effective value of $111.23 \%$. The average effectiveness level of PBB$\mathrm{P}_{2}$ in Kendal Regency during the four years of the 2014 to 2017 period was categorized as effective, indicating that the Kendal Regency Government had implemented optimization of PBB-P2 revenues well.

Although the average effectiveness level of PBB-P2 in Kendal Regency in 2014 to 2017 period was categorized as effective, but the realization of PBB-P2 in 2014 to 2016 was still less than the target set, this was due to: first, tax object data and tax subject owned by the Kendal Regency Regional Finance Agency is still not as accurate as the existence of double tax object data means that one tax object has more than one SPPT (Notification of Tax Due) and the physical tax object listed in the SPPT is not physically found in the field. Second, there are some elements in the village collection staff (village apparatus) who have not deposited the tax collection funds to the regional treasury. Third, the lack of number of PBB-P2 payment posts that has not yet existed in each sub-regency. Kendal Regency cooperates with Bank Jateng (Central Java Bank) in the PBB-P2 payment service. Bank 
Jateng is only able to provide 10 payment post points, while Kendal Regency consists of 20 sub-regencys. Fourth, the lack of the number of tax employee personnel. The number of tax employees who manage PBB-P2 consists of 37 employees, while the number of villages in Kendal Regency as many as 285 villages with a total tax object of 557.083 , is a deficiency that might hamper the PBB-P2 collection process. In addition, there are obstacles in the field when tax collection such as, constraints in the delivery of SPPT to taxpayers who are not in the tax object area or outside the Kendal Regency area, so that the SPPT cannot be conveyed to the taxpayer. The existence of these constraints led to the Kendal Regency $\mathrm{PBB}-\mathrm{P}_{2}$ realization still not achieving the targets set.

PBB-P2 contribution to Kendal Regency's PAD during the four years 2014 to 2017 is included in the criteria of very less because $\mathrm{PBB}-\mathrm{P}_{2}$ revenue occupies the third largest regional tax position after street lighting and BPHTB tax (Land and Building Rights Acquisition Tax). While the PAD source is not only derived from local taxes, but also comes from regional retribution, regional wealth management, and other legitimate PAD.

Classification of $\mathrm{PBB}-\mathrm{P}_{2}$ revenue in Kendal Regency in 2015-2017 is included in the potential revenue classification because the growth ratio of $\mathrm{PBB}-\mathrm{P}_{2}$ to total regional tax growth is less than one and the ratio of proportion (contribution) $\mathrm{PBB}_{-} \mathrm{P}_{2}$ to the average local tax revenue is greater or equal to one. In 2015 proportion and growth ratio of PBB-P2 were 2.18 and 0.77 respectively with potential revenue classification. Then the proportion and growth ratio of PBB-P2 in 2016 were 1.98 and 0.91 respectively with potential classification. Furthermore, in 2017 the proportion and growth ratio of $\mathrm{PBB}-\mathrm{P}_{2}$ were 1.79 and 0.91 respectively with potential revenue classification.

PBB-P2 in Kendal Regency is included in the potential tax category, because it is the third largest tax of 11 types of regional taxes in Kendal Regency, but if seen based on its growth, PBB-P2 revenues in Kendal Regency in the 2014-2017 period still experience negative growth in 2015 amounted to $10.68 \%$. So that efforts are needed to increase the growth of PBB-P2 revenues in Kendal Regency. According to the Ministry of Republic of Indonesia Finance (2014) if local taxes are included in the category of potential revenue, the effort that needs to be done is to intensify the collection of existing tax objects so that there is a growth in tax revenue.

Based on the combined opinion of key persons show that the most important criteria in increasing PBB-P2 acceptance in Kendal Regency is the taxpayer participation criteria (weight value 0.285 ). The next criteria are the HR (Human Resources) tax management criteria (weight value 0.280), tax administration and service criteria (weight value 0.248 ), and tax management policy criteria (weight value o.188). The criteria for taxpayer participation is the most important priority in increasing $\mathrm{PBB}-\mathrm{P}_{2}$ revenues in Kendal Regency, because based on the facts in the field, it shows that the level of taxpayer compliance in carrying out the obligation to pay taxes still has a percentage of $70-80 \%$.

AHP analysis is used to determine aspects that provide information about what must be corrected or implemented in 
increasing PBB-P2 revenues in Kendal Regency. The results of this analysis are obtained from the key persons who are respondents. Each aspect that becomes a criterion is then sorted from the most priority to less being prioritized. Each criterion has several policy alternatives with varying priority levels. From each of these alternatives, it has advantages and disadvantages that will complement and synergize in order to increase $\mathrm{PBB}_{-} \mathrm{P}_{2}$ revenues in Kendal Regency.

The criteria that are the main priority in increasing PBB-P2 revenues in Kendal Regency are of taxpayer participation aspect. Taxpayer participation aspect consists of two alternatives including: increasing taxpayer participation and increasing taxpayer compliance. The alternative to increase taxpayer participation is the most important priority in increasing $\mathrm{PBB}_{2} \mathrm{P}_{2}$ revenue in Kendal Regency from the aspect of taxpayer participation with a percentage of $52.4 \%$. Furthermore, the second priority alternative from the aspect of taxpayer participation is to increase taxpayer compliance with a priority percentage of $47.6 \%$.

The next aspect that becomes the second priority in increasing $\mathrm{PBB}-\mathrm{P}_{2}$ revenues in Kendal Regency is HR (Human Resources) tax management aspect with a percentage of $28 \%$. The HR aspect of the tax manager has three alternatives, including: holding tax collector education and training, providing tax management incentives, and increasing the number of tax employee personnel. The alternative to hold tax collector education and training are top priorities in the aspect of HR tax management with a percentage of $43 \%$. The alternative in the second priority from the HR tax management aspect is an alternative to increase the number of tax employees with a percentage of $31.5 \%$. Then the alternative in the third priority from the aspect of HR tax management is the provision of tax management incentives with a percentage of $25.4 \%$.

In administration and tax service aspects are the third priority in increasing $\mathrm{PBB}-\mathrm{P}_{2}$ revenue in Kendal Regency, with a percentage of $24.3 \%$. In the administrative and tax service aspects there are three alternatives, including: improving the tax database through tax objects and subjects re-collection, picking up the ball service, increasing the number of tax payment service posts. An alternative that becomes the main priority in the administration and tax service aspects is to improve the tax database through tax objects and subjects re-collection, with a percentage of $51.9 \%$. The alternative that becomes the second priority of the tax administration and service aspect is to increase the number of tax payment service posts by a percentage of $25.5 \%$. Then, alternative pick-up the ball service is the third priority in tax administration and service aspects with a percentage of $22.6 \%$.

Furthermore, the aspect that becomes the fourth priority in increasing $\mathrm{PBB}-\mathrm{P}_{2}$ revenue is tax management policy aspect. In tax management policy aspect there are five alternatives used, including: the application of rewards and sanctions in tax collection system, socialization, the implementation of taxpayer compliance testing, improving supervision or monitoring, and adjusting NJOP (Sales Value of Taxable Object) close to market prices. Alternatives to improve supervision or monitoring are the main priorities in tax management policy aspect, with a percentage of $24.1 \%$. The alternative in the second priority 
in tax management policy aspect is socialization with a percentage of $21 \%$. The alternative implementation of taxpayer compliance test is the third priority in tax management policy aspect with the same percentage of $19.6 \%$. Then, the alternative that becomes the fourth priority in tax management policy aspect is the implementation of rewards and sanctions system in tax collection with a percentage of $18 \%$. Furthermore, the alternative which becomes the fifth priority in the tax policy aspect is the NJOP (Sales Value of Taxable Object) adjustment that is close to the market price with a percentage of $17.1 \%$.

The results of the overall analysis show that the policy of increasing taxpayer participation is a top priority alternative when compared with other alternatives in increasing PBB-P2 revenues in Kendal Regency. The second priority is to conduct education and training of tax collectors from the aspect of $\mathrm{HR}$ tax management, with a percentage of $11.4 \%$. The third priority is to increase taxpayer compliance from taxpayer participation aspect with a priority percentage of $10.6 \%$. Then the fourth priority is to improve the tax database through tax objects and subjects re-collection from of tax administration and service aspect with a percentage of $10.1 \%$. Furthermore, the alternative which becomes the fifth priority is to increase the number of tax employee personnel from HR tax management aspect with a priority percentage of $8.4 \%$.

The sixth alternative priority is $7.7 \%$, namely increasing supervision or monitoring of tax management policy aspect. The seventh alternative priority is the provision of tax management incentives from the HR tax management aspect with a priority percentage of $6.8 \%$. The eighth priority is socialization from tax management policy aspect with a percentage of $6.7 \%$. Then, the ninth priority is the implementation of tax compliance test from the tax management policy aspect with a percentage of $6.2 \%$. The tenth alternative priority is the implementation of a reward and sanction system in tax collection from tax management policy aspect with a percentage of $5.7 \%$.

The eleventh alternative priority is NJOP (Sales Value of Taxable Object) adjustment that is close to the market price from tax management policy aspect with a priority percentage of $5.4 \%$. Then, the twelfth alternative priority is to increase the number of tax payment services from the tax administration and service aspect by a percentage of $5.0 \%$ and the alternative that becomes the last priority is the service of picking up the ball from the tax administration and service aspect with a percentage of $4.4 \%$.

\section{CONCLUSION}

The development of PBB-P2 revenues in Kendal Regency in 2014 to 2017 tended to increase, except in $2015 \mathrm{PBB}-\mathrm{P} 2$ realization experienced a decline in revenue of $10.68 \%$. The average growth of $\mathrm{PBB}-\mathrm{P}_{2}$ in Kendal Regency in 2014-2017 was $5.23 \%$. The average level of effectiveness of $\mathrm{PBB}-\mathrm{P}_{2}$ receipts in Kendal Regency in 2014-2017 was 95.63\% included in the effective criteria. The average contribution of $\mathrm{PBB}-\mathrm{P}_{2}$ to Kendal Regency PAD in $2014-2017$ was $5.79 \%$ with very little contribution criteria. The classification of PBBP2 revenues in Kendal Regency in 2015-2017 is included in the potential revenue category, so 
that it can become a regional government mainstay, because the magnitude of PBB-P2 contribution is above the regional tax average, but because the management has not been maximized, the PBB-P2 growth is not stable. This can be seen from the $\mathrm{PBB}-\mathrm{P}_{2}$ revenue which still experienced negative growth in 2015 of $10.68 \%$. If local tax is included in the category of potential revenue, then the effort that needs to be done is to intensify collection of existing tax objects so that there is a growth in tax revenue. Based on the results of the AHP analysis shows that the taxpayer participation criterion (0.285) is the main priority to increase PBB-P2 revenue in Kendal Regency. This is based on the facts in the field which shows that taxpayer compliance level in carrying out the obligation to pay taxes still has a percentage of $70-80 \%$ which is still lacking if you want to increase $\mathrm{PBB}-\mathrm{P} 2$ revenue in Kendal Regency. The next criterion which becomes the second priority is HR tax management with a weight value of 0.280 . Then the third priority is the tax administration and service criteria with a weight value of 0.248 and the last criteria becoming the fourth priority is tax management policy with a weight value of 0.188 .

\section{REFERENCES}

BAKEUDA Kabupaten Kendal. (2017). Rekapitulasi Ketetapan dan Realisasi PBB-P2 Tahun 2014 - 2017 Kabupaten Kendal. Badan Keuangan Daerah Kabupaten Kendal.

Direktorat Jenderal Pajak Kementerian Keuangan. (2012). Pengalihan PBB Perdesaan dan Perkotaan. Dipetik Maret Kamis, 16, 2017, dari http://www.pajak.go.id/content/pengalihan-pbbperdesaan-dan-perkotaan?lang=en

Febiandani, R., \& Suseno, D. A. (2016). Analisis Hubungan Kemandirian Keuangan Daerah dan Ketergantungan Daerah Terhadap Pengangguran dan Kemiskinan. Economic Development Analysis Journal, 5(2), 217-225.

Kementerian Keuangan Republik Indonesia. (2014). Pedoman Umum Pengelolaan Pajak Bumi dan Bangunan Perdesaan dan Perkotaan. Dipetik Maret Minggu, 18, 2018, dari https://www.kemenkeu.go.id/sites/default/files/P edoman_Umum_Pengelolaan_PBB_P2.pdf

Kuncoro, M. (2010). Dasar-dasar Ekonomika Pembangunan (Kelima ed.). Yogyakarta: UPP STIM YKPN.

Lianawati, A. (2015). Efektivitas dan Kontribusi Penerimaan Bea Perolehan Hak Atas Tanah dan Bangunan. Economics Development Analysis Journal, 4(2), 212-222.

Undang-Undang Nomor 28 Tahun 2009 Tentang Pajak Daerah dan Retribusi Daerah.

Undang-Undang Nomor 23 Tahun 2014 Tentang Pemerintah Daerah.

Ristanti, Y. D. (2017). Undang-Undang Otonomi Daerah dan Pembangunan Ekonomi Daerah. Jurnal Riset Akuntansi Keuangan , 2(2), 117-122 